\title{
An Analysis of Mercury (Hg) Levels in Face Whitening Cream Circulated at Lueng Putu Market, Bandar Baru District
}

\author{
T. Khairol $\operatorname{Razi}^{1^{*}}$ \\ ${ }^{1}$ Jabal Ghafur College of Health Sciences, Sigli, Aceh, Indonesia \\ *Corresponding Author: T. Kharol Razi, ${ }^{\text {tkhairolrazimt@gmail.com }}$
}

\begin{abstract}
Whitening cream is a type of cosmetics containing various chemical substances that can lighten dark spots on the skin. Prolonged use of whitening cream is claimedto be able to reduce or even eliminate hyperpigmentation on the skin. However, many whitening creams contain mercury which can cause pigmentation with permanent damages on the skin and body. The creams sometimes have no BPOM permission and are sold at a cheap price. This study thus aimed to investigate the presence of Mercury (Hg) in facial whitening creams of two different brands, namely Natural 99 and Collagen Night, circulating at Lueng Putu Market, Bandar Baru District, Pidie Jaya Regency. These brands were selected because they are popular among women living around the Lueng Putu market. This type of research was experimental. Based on the examination of the mercury content in two samples using a positive atomic absorption spectrophotometer method, it was found that there ismercury $(\mathrm{Hg})$ with level of 176.2578 in Sample1 and level of 172.7299 in Sample 2.This concentration exceeds the threshold set by the BPOM RI Number 12 of 2019, which should be no more than $1 \mathrm{mg} / \mathrm{kg}$ or $1 \mathrm{mg} / \mathrm{L}$ (ppm). It is thus suggested that customers stop using the creamsto avoid their dangerous effects. For detoxification purpose, customers should use skin care products with natural ingredients, such as fruit masks for external treatment, andconsume fruit, vegetables, and more water for internal treatment.Consulting a doctor is highly advised before and after using certain whitening creams.
\end{abstract}

Keywords: Mercury Level, Face Whitening Cream.

\section{Introduction}

White and bright skin has been the beauty standard in Indonesia. This encourages many people, particularly women, to use products that can brighten their skin. Skin functions to protect parts of the body from various disturbances and external stimuli by forming a biological mechanism, one of which is the formation of the melanin pigment to protect the skin from the dangers of the sun's ultraviolet rays. Ultraviolet radiation from the sun can cause various skin problems, such as redness, black spots, premature aging, dryness, wrinkles, and skin cancer. To overcome these problems, it is recommendedthat people use cosmetic treatments (Upik, 2016).

Whitening cream is a type of cosmetics containing various chemical substances to lighten dark spots on the skin. Prolonged use of whitening cream is claimed to be able to reduce or even eliminate hyperpigmentation on the skin. However, many whitening creams contain mercury which can cause pigmentation with permanent damages on the skin and body(Upik, 2016).Mercury is a dangerous heavy metal which can be toxic, even in a small concentration. The use of mercury in whitening creams can result in various skin problems, such as dark spots, allergies, and skin irritation. The use of mercuryata high dosecan even cause permanent damages to the brain, kidneys, and impaired fetal 
development. Its short-term use at a high dose can also cause vomiting, diarrhea, lung damage and cancer (Parengkuan, 2015).

Mercury is often added to whitening cream because it can act as an active ingredient that inhibits the formation of melanin in the skin. However, previous research findings show that it has dangerous toxic effects. Creams containing mercury can cause disturbances to the body's organs as well asskin irritation, such as skin burns, which turns black and become skin cancer (Puspitasari et al., 2018).

Whitening creams sold at markets without a BPOM registration number have been tested positive for mercury (Mongdong et al., 2019). In a study conducted by Parengkuan (2013) on 10 samples of illegal cosmetics in a city of Manado with no BPOM registration numbers, 5 out of 10 samples were tested positive for mercury ( $\mathrm{Hg})$. In Anggraeni's research (2018), all of the five samples studied contain mercury with levels ranging from $51.576 \mathrm{ppm}$ to $3886.776 \mathrm{ppm}$.

Customers are often not aware of the presence of mercury in the whitening cream they use. They are simply tempted to buy it because it promises to brighten the skin and eliminate dark spots quickly. They often buy it at a cheap price and with no BPOM's registration number. This research thus aimed to investigate the presence of mercury in two popular whitening cream brands (Natural 99 and Collagen Night Cream) circulating at the Lueng Putu Market, Bandar Baru District, Pidie Jaya Regency.

\section{Method}

This research is experimental (with laboratory tests) to determine the mercury levels in two facial whitening creams circulating at the Lueng Putu market, Bandar Baru District, Pidie Jaya Regency.A quantitative test with the Atomic Absorption Spectrophotometry (AAS) method was employed. The population in this study were all face whitening creams with no BPOM's registration numbers at the Lueng Putu market, Pidie Jaya Regency in 2021. Two brands were selected as samples based on a simple random sampling formula and pot packaging.

Primary data from lab testswere processed manually by sorting and recapitulating the data to prepare them for the next stage.In this study, the data from laboratory test results consisting of quantitative method tests with spectrophotometry were tabulated in tables and analyzed descriptively.

\section{Results and Discussions}

\section{Sampling}

The following were the research samplesobtained from a cosmetic seller at theLueng putu market. There were two samples in total; both of whichdid not have BPOM registration numbers.

Table 1.Sampling

\begin{tabular}{clcc}
\hline No. & Cream Sample & Shop Address & Sample Code \\
\hline 1. & Natural 99 & Lueng Putu Market & 1 \\
\hline 2. & $\begin{array}{l}\text { Callogen Night } \\
\text { Cream }\end{array}$ & Lueng Putu Market & 2 \\
\hline
\end{tabular}

\section{Laboratory Test Results}

In this study, the mercury content was examined by a third party at the Center for Drug and Food Control (BBPOM), Banda Aceh. The samples were received by the BBPOM on 
May 28, 2021, and examined on June 9, 2021. The laboratory test results of Sample 1 and Sample 2 were as follows:

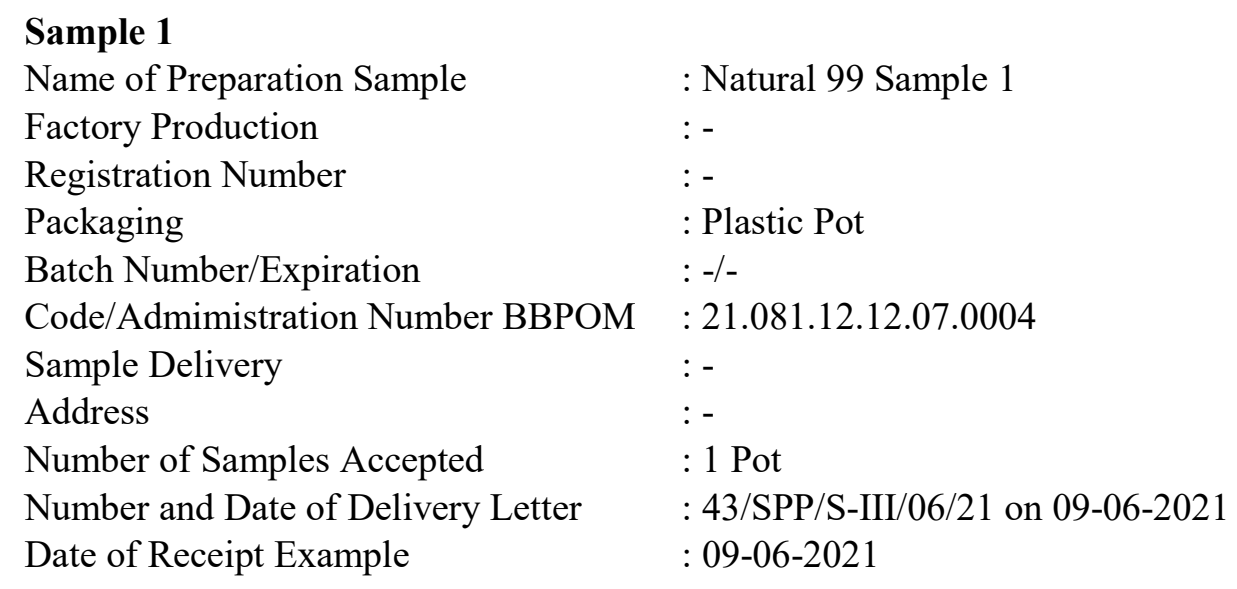

Table 2.Laboratory Test Results on Mercury Content in Face Whitening Creams at the Lueng Putu Market

\begin{tabular}{|c|c|c|c|}
\hline Parameter Test & Result & Terms/Requirements Library & Method Library \\
\hline \multicolumn{4}{|l|}{ Physics } \\
\hline Form & Semi solid & - & \\
\hline Color & Shiny white & - & \\
\hline Smell & Normal & - & \\
\hline \multicolumn{4}{|l|}{ Chemical } \\
\hline Identification of $\mathrm{Hg}$ & (+) Positive & (-) Negative & $\begin{array}{c}\text { MA PPPOMN } \\
\text { 53/KO/13 ACM } 005\end{array}$ \\
\hline $\begin{array}{l}\text { Determination of } \\
\text { Hg levels }\end{array}$ & 176,2578 & $\begin{array}{l}\text { Not more than } 1 \mathrm{mg} / \mathrm{kg} \text { or } 1 \mathrm{mg} / 1 \\
(1 \mathrm{bpj})\end{array}$ & \\
\hline
\end{tabular}

FromTable2, it can be seenthat Sample 1 was tested positive $(+)$ for mercury with the Hg level of 176.2578.

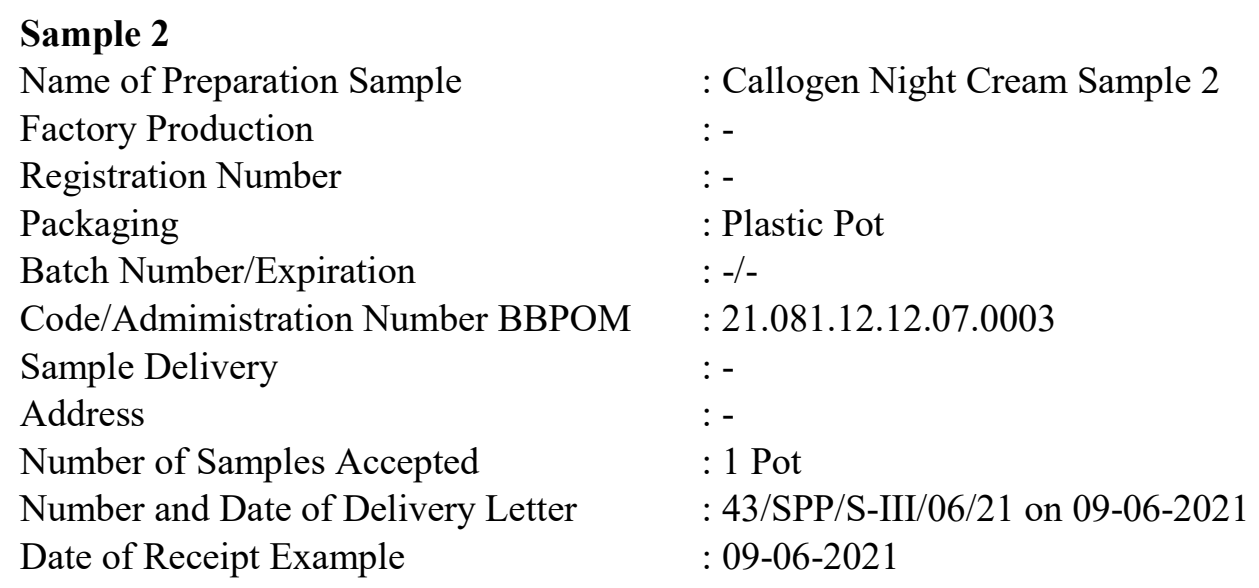

Table 3.Laboratory Test Results on Mercury Content in Face Whitening Cream at the Lueng Putu Market

Parameter Test Result Terms/Requirements Library Method Library




\begin{tabular}{lllr}
\hline Physics & Semi solid & - \\
Form & $\begin{array}{l}\text { Shiny white } \\
\text { Color }\end{array}$ & - & \\
Sormall & - & \\
\hline Chemical & & $(-)$ Negative & MA PPPOMN \\
Identification of Hg & $(+)$ Positive & 53/KO/13 ACM 005 \\
Determination of & 172,7299 & $\begin{array}{l}\text { Not more than } 1 \mathrm{mg} / \mathrm{kg} \text { or } 1 \mathrm{mg} / 1 \\
(1 \mathrm{bpj})\end{array}$ & \\
Hg levels & & & \\
\hline
\end{tabular}

Table 2 shows that Sample 2 also contains mercury with $\mathrm{Hg}$ level of 172.7299.

\section{Test Results Using Atomic Absorption Spectrophotometer Method Chart 1. Research Analysis}

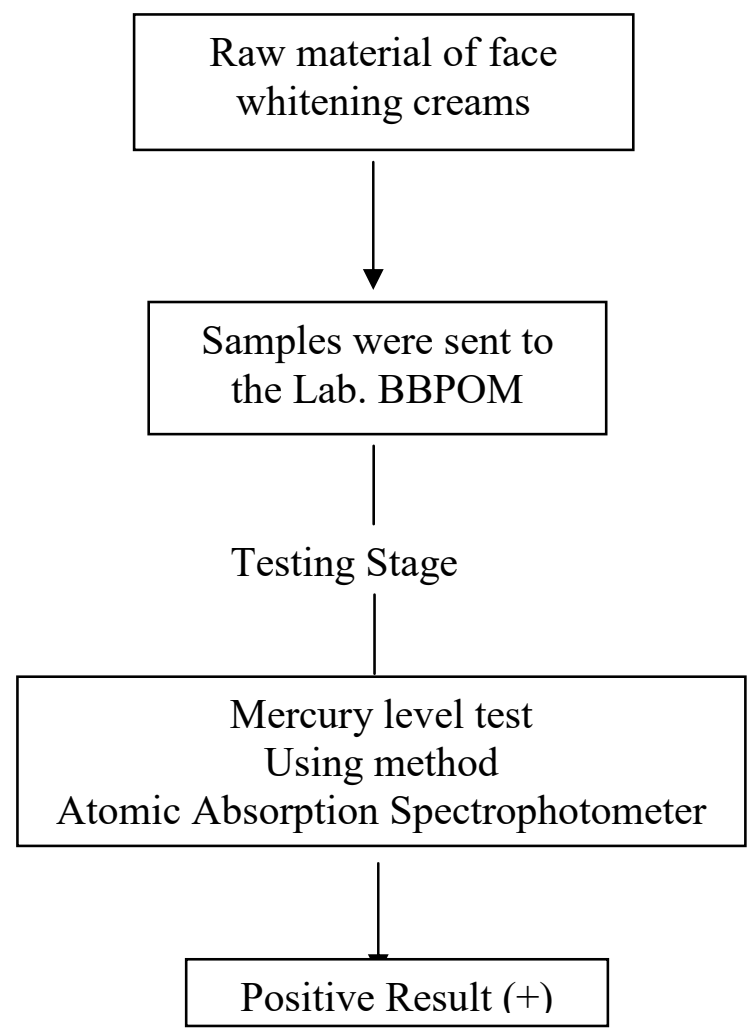

Description:The sample is positive because it contains mercury levels that exceed the specified threshold (1 ppm)

Based on the chart above, we can see that the research samples were facial whitening creams. The sampleswere then sent to the BBPOM of Banda Aceh on May 28, 2021 to be tested by a third party.The analysis of mercury content in this facial whitening cream was carried out using the Atomic Absorption Spectrophotometer testing method becauseit can measure the levels of metalaccurately, even in a very small quantity. The analysis results showed that mercury, which is known as a very toxic and heavymetal, is present in both samples. The amount of mercury in each cream is different, with Sample 1 having the $\mathrm{Hg}$ level of 176.2578 while Sample 2 having theHg level of 172.7299. These exceed the 
threshold set by BPOM RI Number 12 of 2019, which is no more than $1 \mathrm{mg} / \mathrm{kg}$ or $1 \mathrm{mg} / \mathrm{L}$ (ppm).

According to Parengkuan (2015), whitening creams containing mercury will make the skin white and smooth in a short time, but it will later causedark spots on the skin, allergies, and skin irritation. The use of mercury at a high dose can cause permanent damages to the brain, kidneys, body, and fetal development. Even short-term exposure at a high dose can cause vomiting, diarrhea, lung damage as well as cancer.

\section{Conclusions}

It can be concluded that both of the studied samples contain mercury,with Sample 1 having the $\mathrm{Hg}$ level of 176.2578 while Sample 2 having the $\mathrm{Hg}$ level of 172.7299. This concentration exceeds the threshold set by the BPOM RI Number 12 of 2019, which should be no more than $1 \mathrm{mg} / \mathrm{kg}$ or $1 \mathrm{mg} / \mathrm{L}$ (ppm). It is thus suggested that customers stop using the creams to avoid their dangerous effects, and be more careful in choosing cosmetic products. For detoxification purpose, customers who have used facial creams with mercuryare recommended to use skin care products with natural ingredients, such as fruit masks for external treatment, and consume fruit, vegetables, and more water for internal treatment. Consulting a doctor is highly advised before and after using certain whitening creams.

\section{References}

Anggraeni, A., \& Faridah, F. (2018). Analisis Cemaran Logam Berat Merkuri dalam Krim Pemutih Wajah yang Beredar di Pasar Tradisional dengan Metode Spektro fotometri Serapan Atom. Journal of Pharmacopolium, 1(1).

Mongdong, A., Mongi, J., Paat, V., \& Pareta, D. (2019). Analisis Kandungan Merkuri pada Krim Pemutih yang Beredar di Pasar Tomohon dan Tondano. BiofarmasetikalTropis, 2(1), 91-96.

Parengkuan, K., Fatimawali \& Citraningtyas, G. (2013). Analisis Kandungan Merkuri pada Krim Pemutih yang Beredardi Kota Manado. Jurnal Ilmiah Farmasi-UNSRAT, 2(1).DOI: https://doi.org/10.35799/pha.2.2013.886

Puspitasari, A., Lestari, I., \& Dyah Wulandari, D. (2019). Analisis Kadar Merkuri dan Hidrokuinon dalam Kosmetik Krim Pemutih yang Dijual di Online Shop. MPI (Media Pharmaceutica Indonesiana), 2(2), 98-104. https://doi.org/10.24123/mpi.v2i2.1289

Rohaya, U., Ibrahim, N., \& Jamaluddin, J. (2017). Analisis Kandungan Merkuri (Hg) pada Krim Pemutih Wajah Tidak Terdaftar yang Beredar di Pasar Inpres Kota Palu: Analysis of the Content of Mercury (Hg) in Unregistered Facial Whitening Creams Circulating in the Inpres Market of Palu. Jurnal Farmasi Galenika (Galenika Journal of Pharmacy) (e-Journal), 3(1), 